\title{
Summer 2021 marine heat wave in the Gulf of Finland from the perspective of climate warming
}

\author{
Ülo Suursaar \\ Estonian Marine Institute, University of Tartu, Mäealuse 14, 12618 Tallinn, Estonia; ulo.suursaar@ut.ee \\ Received 21 October 2021, accepted 1 December 2021, available online 20 January 2022

\begin{abstract}
The summer 2021 heat waves (HWs) and marine heat waves (MHWs) were analysed on the basis of air and water temperatures measured both in the open part of the Gulf of Finland at buoys and lighthouses and some land-based stations. The summer of 2021 (June, July, August) was the hottest on record in Estonia with distinct HW episodes around 18-23 June, 4-10 July and 13-18 July. Water temperatures reached up to $26.5^{\circ} \mathrm{C}$ at the Kunda coastal station on 16 July and up to $28.1{ }^{\circ} \mathrm{C}$ at the NarvaJõesuu coastal station on 15-16 July. At the Gulf of Finland wave buoys, high water temperatures were measured on $14 \mathrm{July:} 26.6^{\circ} \mathrm{C}$ (24-h average $\left.25.5^{\circ} \mathrm{C}\right)$ in the central part of the gulf and $27.9^{\circ} \mathrm{C}\left(24\right.$-h average $\left.25.8^{\circ} \mathrm{C}\right)$ at the Kotka buoy. Analysis of satellite sea surface temperature (SST) data showed that the gulf-wide average SST was $26.3{ }^{\circ} \mathrm{C}$ on $15 \mathrm{July}$. The MHW events were interrupted by several coastal upwelling (CU) episodes, occasionally causing water temperatures lower than $5^{\circ} \mathrm{C}$. The $\mathrm{CU}$ events occurred either on the gulf's northern side, with prevailing westerlies, or its southern side, with easterlies. A comparison of summers suggested the following ranking of the HWs, valid for the region of the Gulf of Finland in 2010-2021: 2021 and 2010 (more or less a tie), 2018, 2014, 2011 and 2019. In the ranking of the MHWs, the summer of 2021 clearly was the first, followed (tied) by those of 2014,2010 and 2018. Because of the remarkable warming trend in the Baltic Sea area over the last half-century, it is unlikely that any other summer from earlier periods could have had more influential HWs and MHWs than the summers of 2021 and 2010 had.
\end{abstract}

Key words: sea surface temperature, satellite images, heat waves, coastal upwelling, climate change, Baltic Sea.

\section{INTRODUCTION}

Under the warming climate, heat waves (HWs) and their manifestations in the sea, i.e. marine heat waves (MHWs), are expected to occur in increasing frequencies and magnitudes in Europe. Such trends have been specifically analysed e.g. by Schär et al. (2004), Beniston et al. (2007), Russo et al. (2015) and Lhotka et al. (2018), but the same prospects can be indirectly inferred form the facts that the global climate has already warmed by $c a 1.1^{\circ} \mathrm{C}$ over the last 100 years (IPCC 2014), including a 1.5-2-degree rise in the Baltic Sea area over the last 50-60 years (e.g. Kont et al. 2007; Rutgersson et al. 2015). According to the EU Copernicus data (CMEMS 2021a) for the Baltic Sea (1993-2019), monthly mean sea surface temperature (SST) series contain a statistically significant $0.97{ }^{\circ} \mathrm{C}$ increase by linear trend just over the last 27 years $(0.036$ $\pm 0.004{ }^{\circ} \mathrm{C} /$ year), which is much faster than the global average. Earlier, Siegel et al. (2006) have reported a $0.8^{\circ} \mathrm{C}$ increase in the mean SST of the Baltic Sea over a 15 -year period in 1990-2004.
Although magnitudes and occurrence statistics of HWs vary geographically, the universal threats they pose in warming climate conditions include testing the established tolerance limits of ecosystems (Easterling et al. 2000) and affecting the well-being of people (e.g. Armstrong 2006). Our study area is in the northeastern Baltic Sea and includes the Gulf of Finland and its adjacent coastal areas in northern Estonia and southern Finland (Fig. 1). Even in the Baltic Sea area, which is located in relatively high latitudes $\left(54-65^{\circ} \mathrm{N}\right)$ in the temperate climate zone between maritime and continental conditions (Kont et al. 2007), HWs and MHWs may still have severe societal and environmental consequences, when organism tolerance limits are exceeded (Takolander et al. 2017; Paalme et al. 2020). Excess mortality in human population due to HWs is an increasing problem not only in central and southern Europe (Robine et al. 2008) but has also been recorded e.g. in Finland (Näyha 2007; Ruuhela et al. 2021) and Estonia (Saava et al. 2015).

An HW is usually defined as a period of excessively high temperatures relative to climatological norms in the 


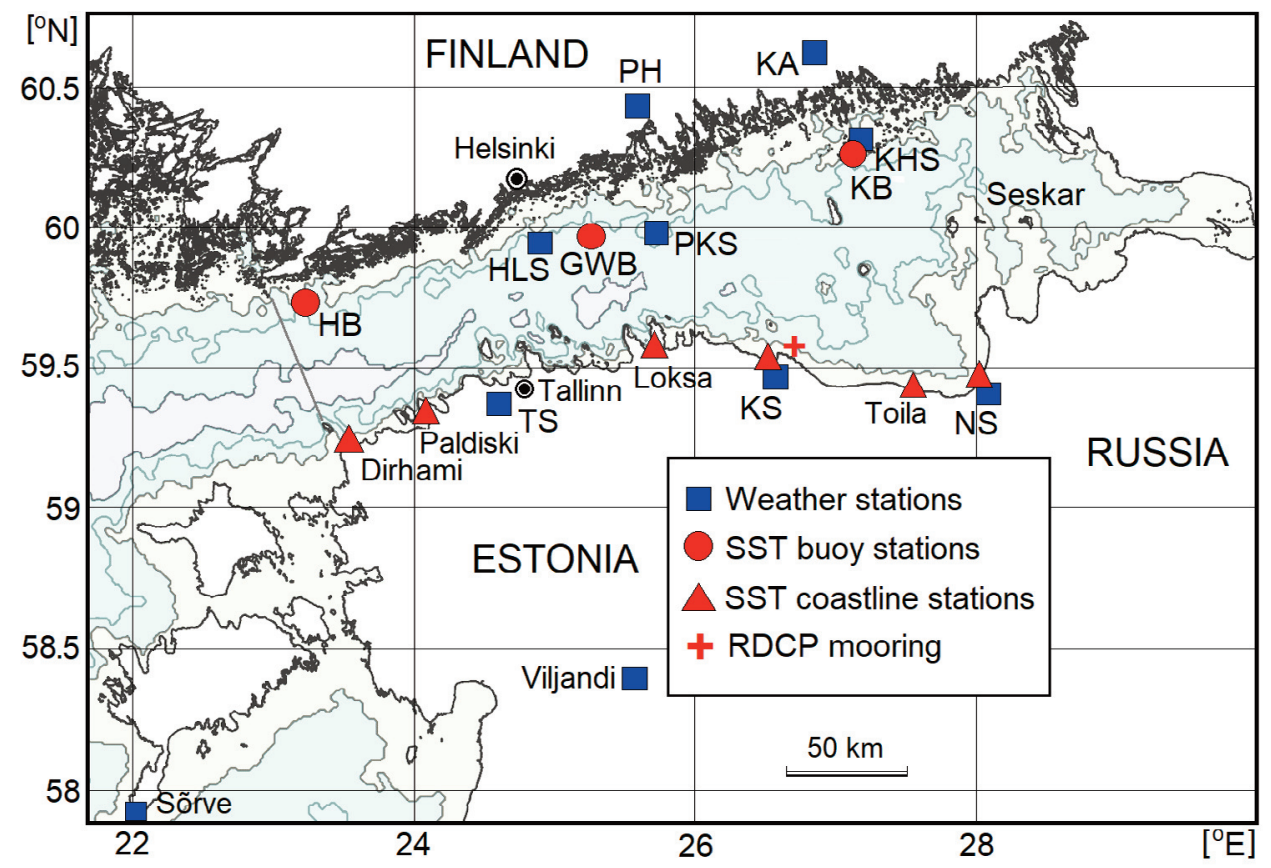

Fig. 1. Map of the study area with the locations of selected marine and weather stations. Water temperature: GWB (Gulf of Finland wave buoy), HB (Hanko Längden buoy), KB (Kotka Kuusenkari buoy), KS (Port of Kunda). Weather data: HLS (Helsinki Lighthouse), PKS (Porvoo Kalbådagrund), KHS (Kotka Haapasaari), PH (Porvoo Harabacka), KA (Kouvola Anjala), KS (Kunda), TS (Tallinn-Harku), NS (Narva, Narva-Jõesuu). Additional water temperature data from NS, KS, Toila, Loksa, Paldiski and Dirhami. + RDCP, Recording Doppler Current Profiler mooring (water temperature and salinity) off the Letipea Peninsula. The border of the Gulf of Finland is marked with a line in the gulf's entrance section.

area and the seasonal phase (e.g. Robinson 2001). For instance, one definition by the World Meteorological Organization (WMO) says that an HW should contain five or more consecutive days on which the daily maximum temperatures exceed the average maximum temperature by $5{ }^{\circ} \mathrm{C}$ or more (Peterson \& Manton 2008; Perkins \& Alexander 2013). A huge number of HW indices have been worked out, which usually consider the aspects like maximum value, duration, and magnitude relative to normal temperatures for the season and area. The temperatures that people from a hotter climate consider normal can be called an HW in some other area (Robinson 2001). Also, the threshold and duration criteria may vary greatly depending on the study and country. There is no clear definition for HWs in Estonia either. In a study by Õispuu (2019), an HW is defined as a period of at least three consecutive days on which the daily maximum temperature is $25^{\circ} \mathrm{C}$ or more. A further gradation includes so-called dangerous events with daily maxima over 27 and $30{ }^{\circ} \mathrm{C}$ on three or more consecutive days. A study by Keevallik \& Vint (2015) considered percentile-based thresholds over 1961-1990 normals by the Estonian Weather Service (EWS). Clear criteria for MHWs are missing as well, because such studies are still rare for the
Baltic Sea. A few examples are provided by Paalme et al. (2020), Suursaar (2020) and She et al. (2020). When studying MHWs, similarly to HWs, both spatial and temporal aspects of the phenomenon should be considered (Hobday et al. 2018; Oliver et al. 2019).

Recent studies have already highlighted a number of summers that have been abnormally hot in Europe. One of such all-Europe rankings (Russo et al. 2015), covering 1950-2015, includes the years 2010, 2003, 1972, 1976, 1969, 2015, 2007, 1994, 2014, 1954 and 2006 (in that order). Of those, only 2010, 2003, 1972, 1994, 2014 and 2006 have directly influenced the Baltic Sea area. An Estonia-based analysis for the period 1951-2018 by Õispuu (2019) suggested the ranking of 2010, 2018, 2014, 2003 and 1994 (Fig. 2). The summer of 1992, which has shown some presently known air temperature maxima (including the absolute maximum of $35.6{ }^{\circ} \mathrm{C}$ measured in Võru on 11 August 1992), had just a few extremely hot days which, however, did not form notable HWs. After 2018, the summers of 2019 and 2020 have globally been among the hottest (Cheng et al. 2020; NOAA 2021). Considering preliminary meteorological reports from various countries in Europe and North America, this line continued in the summer of 2021 with some record- 


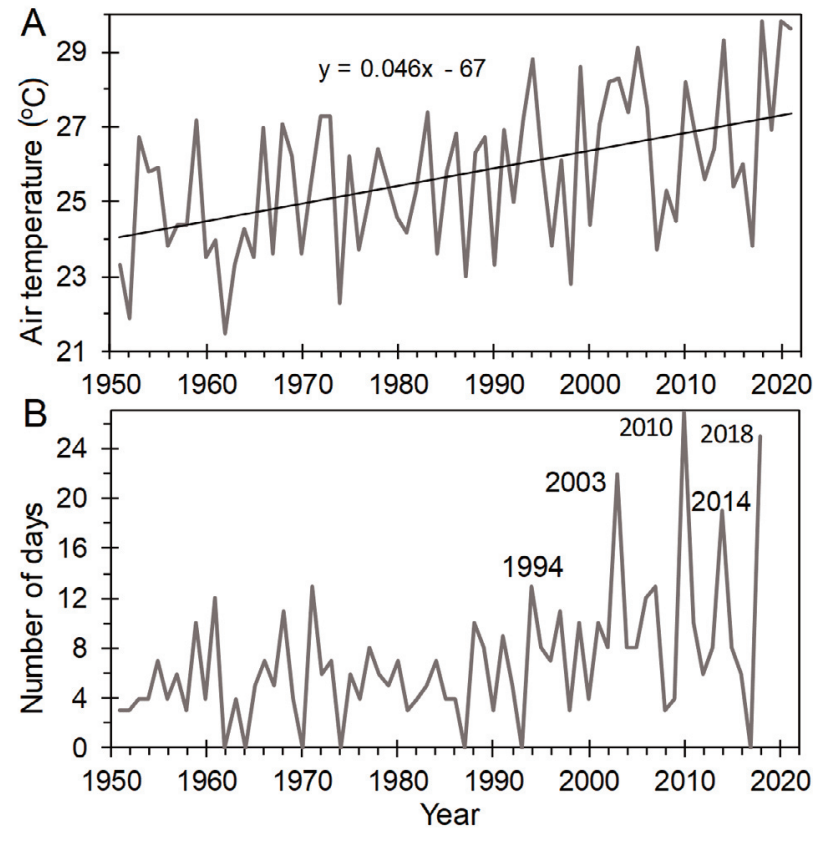

Fig. 2. Examples illustrating warming tendencies in Estonia over the last 70 years (updated from Õispuu 2019). A, annual maximum air temperatures with a (statistically significant) linear trend at Sorve in 1951-2021. B, lengths of annual longest heat waves $\left(>25^{\circ} \mathrm{C}\right)$ at Viljandi in 1951-2018. Note that such long series are not instrumentally homogeneous (e.g. Keevallik \& Vint 2012), which may artificially magnify the trends.

breaking air temperatures and HWs. According to the EU Copernicus Climate Change Service, the average surface air temperature in June-August 2021 was $1.0^{\circ} \mathrm{C}$ above the 1991-2020 average, making this summer the hottest in the data set available for Europe. The previous warmest summers, 2010 and 2018 , were $0.1{ }^{\circ} \mathrm{C}$ cooler (CMEMS 2021b). The $2021 \mathrm{HWs}$ were well covered also in newspaper articles, which shows that these were not merely a calculated abstraction but were perceived as an extreme event by the general public, too. The HW was extreme also in Estonia (EWS 2021a).

The primary objectives of this article were to analyse some of the meteorological characteristics of the JuneJuly 2021 HW in the Gulf of Finland area and, relying on contact measurements of water temperatures and SST satellite data, to document the July 2021 MHW in the gulf. Other aims were to assess and grade the most important MHWs in the Gulf of Finland over the last decades and to study their life cycles and termination by hydrometeorological processes, such as coastal upwelling (CU). To ensure the integrity of the comparison, the period from 2010 to 2021 was covered, although some of the data series span much further back in time. Some older events are briefly discussed as well.

\section{MATERIAL AND METHODS}

\section{Overview of data}

As MHWs are generally caused by HWs in the same area, the study covers both phenomena. Regarding SST data, we concentrated on time series obtained from the open part of the Gulf of Finland (at three buoy stations; Fig. 1), one coastal station (Kunda) and on satellite-based spatial coverages of SST across the Gulf of Finland. The meteorological description and some time series of atmospheric temperatures were obtained from the lighthouses and coastal stations that are located close to the abovementioned SST data sources (Fig. 1). It is essential to keep in mind that a spatially varying and temporally evolving event like an HW (or an MHW) can be characterized by a large number of parameters and various assessment criteria. Therefore, some of the study results (e.g. ranking of different years) can somewhat vary depending on data choices or areal representations. This study is expected to primarily cover the Gulf of Finland area together with the North Estonia's coastal strip. As HWs usually cover much larger areas (occasionally forming 'heat dome' events), the representative area of this study, with some reservations, can be somewhat broadened.

\section{Marine data}

The study is mainly based on the SST time series registered in the open part of the Gulf of Finland (Fig. 1), as the data from coastal stations may not be representative enough for MHW studies. Located $c a 20 \mathrm{~km}$ off the Finnish mainland, the Gulf of Finland wave buoy (GWB; Suomenlahti aaltopoiju; 59 $57^{\prime} 54^{\prime \prime} \mathrm{N}, 25^{\circ} 14^{\prime} 6^{\prime \prime} \mathrm{E}$ ) has been operational since 1990, but downloadable data are available only from December 2004. The measuring interval is currently $10 \mathrm{~min}$. Additionally, somewhat shorter and less complete time series are available for the Kotka Kuusenkari buoy (KB; 60 $16^{\circ} 18^{\prime \prime} \mathrm{N}, 27^{\circ} 6^{\prime} 28^{\prime \prime} \mathrm{E}$; since 2014 ) and the Hanko Längden buoy (HB; 59 $45^{\prime} 26^{\prime \prime} \mathrm{N}$, $23^{\circ} 13^{\prime} 12^{\prime \prime} \mathrm{E}$; since 2013). All these buoys are operated by the Finnish Meteorological Institute (FMI) and the nearcontinuous, at least hourly time series of near-surface ( $\mathrm{ca}$ $20 \mathrm{~cm}$ depth) water temperatures are downloadable from the website of the FMI (FMI 2021). Our specific study period for MHWs is 2010-2021, for which near-complete data can be obtained from all stations.

On the Estonian side, SST hourly time series from the Kunda coastal station (KS; 59 $31^{\prime} 35^{\prime \prime} \mathrm{N}, 26^{\circ} 32^{\prime} 38^{\prime \prime} \mathrm{E}$; measurements at the Port of Kunda pier, $0.6 \mathrm{~km}$ seawards from the Kunda weather station) by the EWS were analysed. Hourly data for the year 2021 (January to September) and some additional, historical data from 
selected coastline stations (NS, Toila, KS, Loksa, Paldiski Port, Dirhami; Fig. 1) were retrieved (EWS 2021b).

While the wave-buoy and coastal measurements provide temporal variations in SST, satellite imagery can be used for describing instantaneous, spatial SST patterns across the entire Gulf of Finland. Raw data from satelliteborne radiometers mostly originate from NASA, NOAA and EU Copernicus programmes. For this study, the preprocessed images (products) from the TARKKA open web service of the Finnish Environment Institute (SYKE) were used (SYKE 2021). Although the images are available on a nearly daily basis, their usefulness varies due to cloudiness. The images were visually assessed for the most prominent HW periods in the past. Luckily, for the 2021 HW, very good, cloud-free images were available from 15 July and 25 July 2021, representing both the peak-time MHW and the subsequent upwelling conditions. The same also applied to the year $2018 \mathrm{MHW}$, when good images for different MHW phases were available e.g. from 15 and 18 July 2018. In principle, the gaps in the SST images can be compensated using hydrodynamic modelling (e.g. in the Polish SatBaltyk system) to produce daily, 'complete' SST images. As the main focus of this study was on the well-covered year of 2021, it was not necessary to use the mixed sources approach. Satellite-based SST data processing can be considered to have up to $\pm 0.5^{\circ} \mathrm{C}$ accuracy in the Baltic Sea (Uiboupin \& Laanemets 2009; Høyer \& Karagali 2016). There are also principal differences between the sea surface skin temperature observed from satellites, in situ sensors located a few metres below the sea surface and models (Zujev \& Elken 2018; Minnett et al. 2019). In calm summer conditions, the remotely sensed values can be up to $1{ }^{\circ} \mathrm{C}$ higher in the Baltic Sea (Siegel et al. 2006; Konik et al. 2019), and even larger short-term biases can occur close to the coast.

Finally, water temperature variations switching between the MHW and subsequent CU conditions were illustrated based on measurements with a Recording Doppler Current Profiler (RDCP) off the Letipea Peninsula $\left(59^{\circ} 33^{\prime} 0^{\prime \prime}\right.$ N, 26 40'10" E; Fig. 1). Such measurements, previously reviewed by Suursaar \& Aps (2007) and Suursaar (2020), frequently included the imprints of interacting CUs and MHWs (e.g. in 2006 and 2014). Briefly, the frequency of CUs in the Gulf of Finland is around 20\% (e.g. Soomere et al. 2008). Upwelling is triggered by the alongshore wind and it involves an upward motion of dense, usually cooler and saltier water towards the sea surface. In the Gulf of Finland, the persistent easterly wind causes upwelling along the Estonian coast, and the westerly wind causes upwelling along the Finnish coast. In this study, the water temperature and salinity records taken from the $10 \mathrm{~m}$ depth during the summer 2014 HW were used. These measurements spanned from 6 June to 29 September 2014 and included both MHWs and CUs.

\section{Atmospheric data}

On the Estonian side, the meteorological part is based on weather data from stations at Kunda (KS; 59 $31^{\prime} 17^{\prime \prime} \mathrm{N}$, 26³2'29" E), Tallinn-Harku (TS; 59॰23'53" N, 24³6'10" E) and Narva (NS; 59 $23^{\prime} 22^{\prime \prime} \mathrm{N}, 2^{\circ} 06^{\prime} 33^{\prime \prime} \mathrm{E}$; prior to December 2013, at Narva-Jõesuu). Both hourly and daily data are downloadable from the website of the EWS for the period from 2004 to 2021 (EWS 2021c). As Estonian weather stations were re-equipped with MILOS-520 type automated weather complexes in 2003, this data set is instrumentally homogeneous. We used air temperature (hourly averages and hourly maxima) and wind data in this study. It is essential to keep in mind different types of maxima and averages. We derived 24-h average air temperatures, maximum hourly averages and hourly (absolute) maxima. From wind speed and direction data, hourly wind velocity vector components $u$ (W-E, positive direction $\mathrm{E})$ and $v(\mathrm{~S}-\mathrm{N}$, positive to $\mathrm{N})$ were calculated. Negative $u$ (easterly wind) is supposed to represent upwelling-favourable wind conditions along the North Estonian coast (Suursaar 2010).

On the Finnish side, it was possible to choose some stations that are located not on land, but off the coast in the sea (on lighthouses, small islets or buoys; Fig. 1). From the Porvoo Kalbådagrund weather station (PKS; $59^{\circ} 59^{\prime} 8^{\prime \prime} \mathrm{N}, 25^{\circ} 35^{\prime} 56^{\prime \prime} \mathrm{E}$ ), which is located in the central part of the gulf just $16 \mathrm{~km}$ to the east from the GWB, we used daily maximum air temperature data (downloadable data from 1998-2021 with a gap in 2019). Also, data from the Helsinki Lighthouse (HLS; 59 56 '56" N, 245' 34" E) from 2003-2021 (gap in 2018) and data from the Kotka Haapasaari station (KHS; 60 $17^{\prime} 12^{\prime \prime} \mathrm{N}, 27^{\circ} 11^{\prime} 5^{\prime \prime} \mathrm{E}$ ) from 2000-2021 were used. In addition, daily maxima from two nearby continental stations, Porvoo Harabacka (PH; $60^{\circ} 23^{\prime} 30^{\prime \prime} \mathrm{N}, 25^{\circ} 36^{\prime} 26^{\prime \prime} \mathrm{E}$ ) and Kouvola Anjala (KA; $\left.60^{\circ} 41^{\prime} 47^{\prime \prime} \mathrm{N}, 26^{\circ} 48^{\prime} 40^{\prime \prime} \mathrm{E}\right)$ were reviewed for 2010-2021.

\section{Quantification of HW and MHW events}

An HW is usually characterized as a period of excessively high temperatures relative to climatological norms. Another approach is to set some fixed criteria (maximum temperature exceedance, duration) to represent dangerous events. For instance, in Estonia, the gradation currently suggested by the EWS includes daily maxima exceeding $27^{\circ} \mathrm{C}$ (dangerous) and $30^{\circ} \mathrm{C}$ (as very dangerous events) on three or more consecutive days, or daily averages exceeding either 20 or $25^{\circ} \mathrm{C}$ on at least three consecutive days. Norm-based criteria may use e.g. a percentile (90\%) approach or simply adding a constant (usually, $5^{\circ} \mathrm{C}$ ) to 
the long-term norm. It is possible to compare both daily averages and maxima with corresponding norms. Strictly speaking, an HW can then occur regardless of a season in relatively low temperatures as well. However, norms evolve in time. For instance, for Kunda, the norm graph in summer months for $1991-2020$ stays on average $0.5^{\circ} \mathrm{C}$ higher than the graph for 1981-2010, the annual means being 6.2 and $5.6^{\circ} \mathrm{C}$, respectively. Also, it is not easy to calculate daily norms, as the daily values somewhat fluctuate in time. Some kind of smoothing should be applied. Sometimes, time series of maximum temperatures might not be exactly homogeneous, because of changes in the measuring equipment and routines (e.g. Keevallik \& Vint 2012; Suursaar et al. 2015). For instance, the absolute maxima picked up from near continuous recordings (which is possible since 2003) can be slightly higher than the maxima found from discrete hourly (or even more sparse) recordings of earlier times.

In this study, we used the elements of both norm and threshold-based approaches. At Kunda, monthly averages for 1991-2020 (by the EWS) were interpolated into daily values for the summer months. We added $5{ }^{\circ} \mathrm{C}$ to the norm $\left(\mathrm{N}+5^{\circ} \mathrm{C}\right)$. This may slightly underestimate the HWs relative to the 1981-2010 norm, but certainly not overestimate. In addition, we used fixed $27^{\circ} \mathrm{C}$ and $30^{\circ} \mathrm{C}$ threshold criteria for daily maxima. We recorded the maxima and counted the number of consecutive days exceeding these threshold values. Since we did not have recent Kunda water temperature norms, we used the historical monthly averages (Astok \& Mardiste 1995), although we are aware that more recent norms can be higher. The applied $\mathrm{N}+5.5^{\circ} \mathrm{C}$ criterion can partly compensate that difference. In addition, the $22{ }^{\circ} \mathrm{C}$ threshold criterion was set for the Kunda water temperature series as well.

In the case of the Gulf of Finland buoy data, the daily averages were only calculated for the longest (2005-2021)
GWB series. We calculated the averages on a 10-day basis and then interpolated (smoothed) them into daily values. As this series is still too short (16 years; 2009 was missing) and recent, we did not consider it as a proper 'norm'. It just represents the averages over the most recent 15 -year period, which is probably also the hottest in modern history. In addition, event maxima and exceedances of 18-, 20- and 22-degree thresholds were registered. Generally, it is rather difficult to decide which event is more influential (prominent) - the one that lasted longer or another that had higher maxima. Some kind of subjectivity is always involved. In order to compare and rank the various extreme MHW events, cumulative temperatures (in degree-hours) were calculated over these $(18,20,22)$ thresholds. A similar approach is traditionally used e.g. in agro-meteorology (e.g. 'sum of active temperatures' approach; the basis depending on the crop). It helps to compare events with various durations and maxima. Although data from all summers (2010-2021) were reviewed, more detailed comparison included the years that were clearly warmer than the others (i.e. 2010, 2011, 2014, 2018, 2021) (Fig. 3).

\section{RESULTS AND DISCUSSION}

\section{HW and MHW at Kunda in 2021}

Although Estonia's absolute maximum air temperature $\left(35.6{ }^{\circ} \mathrm{C}\right)$ record was not broken, the summer of 2021 (June, July, August) was considered the hottest in Estonia since 1922 (EWS 2021a). The Estonia-wide three-month average $\left(18.6{ }^{\circ} \mathrm{C}\right)$ considerably exceeded the current (1991-2020) norm $\left(16.4{ }^{\circ} \mathrm{C}\right)$, and even more so the previous, historical norms. At Kunda, the summer 2021 average temperature $18.8^{\circ} \mathrm{C}$ (Fig. 3B) was much higher than in the previous hottest summers of $2010\left(17.9^{\circ} \mathrm{C}\right)$
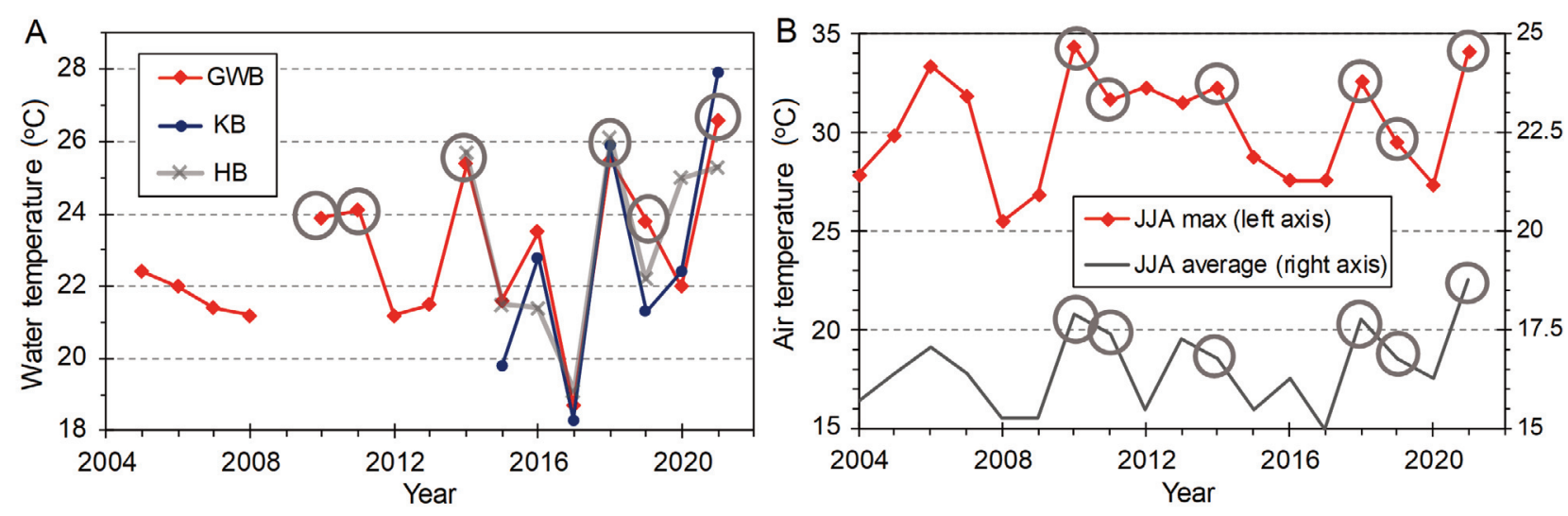

Fig. 3. A, summer SST maxima in the Gulf of Finland at the Gulf of Finland wave Buoy (GWB), Kotka Kuusenkari buoy (KB) and Hanko Längden buoy (HB) in 2005-2021. B, summer (June, July, August - JJA) maximum and average air temperatures at the Kunda station in 2004-2021. The selected years for further analysis of HW/MHW events are circled. 
and $2018\left(17.8^{\circ} \mathrm{C}\right)$, while in absolute maxima, the year $2021\left(34.1^{\circ} \mathrm{C}\right)$ was just behind $2010\left(34.4^{\circ} \mathrm{C}\right)$. The HW was most extreme in June and in northern Estonia, affecting also the water temperatures along the coast. Estonia's historical June record was broken at Narva ( $34.6{ }^{\circ} \mathrm{C}$, on $23 \mathrm{June}$ ). Out of 23 stations, the local record for June was broken at 16 stations in Estonia (EWS 2021a). However, having a much wider spread than that, the June 2021 HW covered large parts of Russia, eastern Europe and Ukraine (Fig. 4). The responsible anticyclone conditions over Russia resembled those in the 2010 or 2014 HWs (Russo et al. 2015), when a huge, stable anticyclone blocked westerlies and cyclonic activity along the polar front for several weeks.

The weather map from 22 June 2021 (i.e. the day before the hottest air temperatures were registered in Estonia) shows amidst large, governing high-pressure systems only some weak lows above Scandinavia and Central Europe (Fig. 4). The atmospheric fronts were relatively weak, spatial differences in surface atmospheric pressure were small, mostly between 1005 and $1020 \mathrm{hPa}$, and hence the winds were weak. During the week before, advection of hot air masses from the south and southeast, better seen in AT850 and AT700 charts (http://www1.wetter3.de/Archiv/) representing the dynamic situation $c a 1.5-3 \mathrm{~km}$ above the surface, had occurred.

According to the hourly SST and air temperature time series at Kunda, several HW and MHW episodes can be identified (Fig. 5; Table 1). Quite naturally, the exact periods and durations of HWs may be slightly different at other stations. Air temperature gradually rose in June and reached $24^{\circ} \mathrm{C}$ by 10 June. Although the daily averages exceeded the norm almost by $5{ }^{\circ} \mathrm{C}$, this short episode did not qualify as an HW, but it nevertheless caused MHW1. It lasted for four consecutive days (more precisely, 4.5 days) according to the $\mathrm{N}+5.5{ }^{\circ} \mathrm{C}$ criterion and was then ended by the upwelling event $\mathrm{CU} 1$ with a minimum of $4.9{ }^{\circ} \mathrm{C}$ on 11 June. According to the $\mathrm{N}+5{ }^{\circ} \mathrm{C}$ criterion, it would have lasted for five days.

The first proper HW lasted for at least six consecutive days from 18 to 23 June (Figs 4, 5), when Estonia's new June record $34.6{ }^{\circ} \mathrm{C}$ was established. A slightly shorter $(5+1$ days, with one cooler day in between) and less extreme (max $33.9^{\circ} \mathrm{C}$ on 10 July) $\mathrm{HW} 2$ was registered on

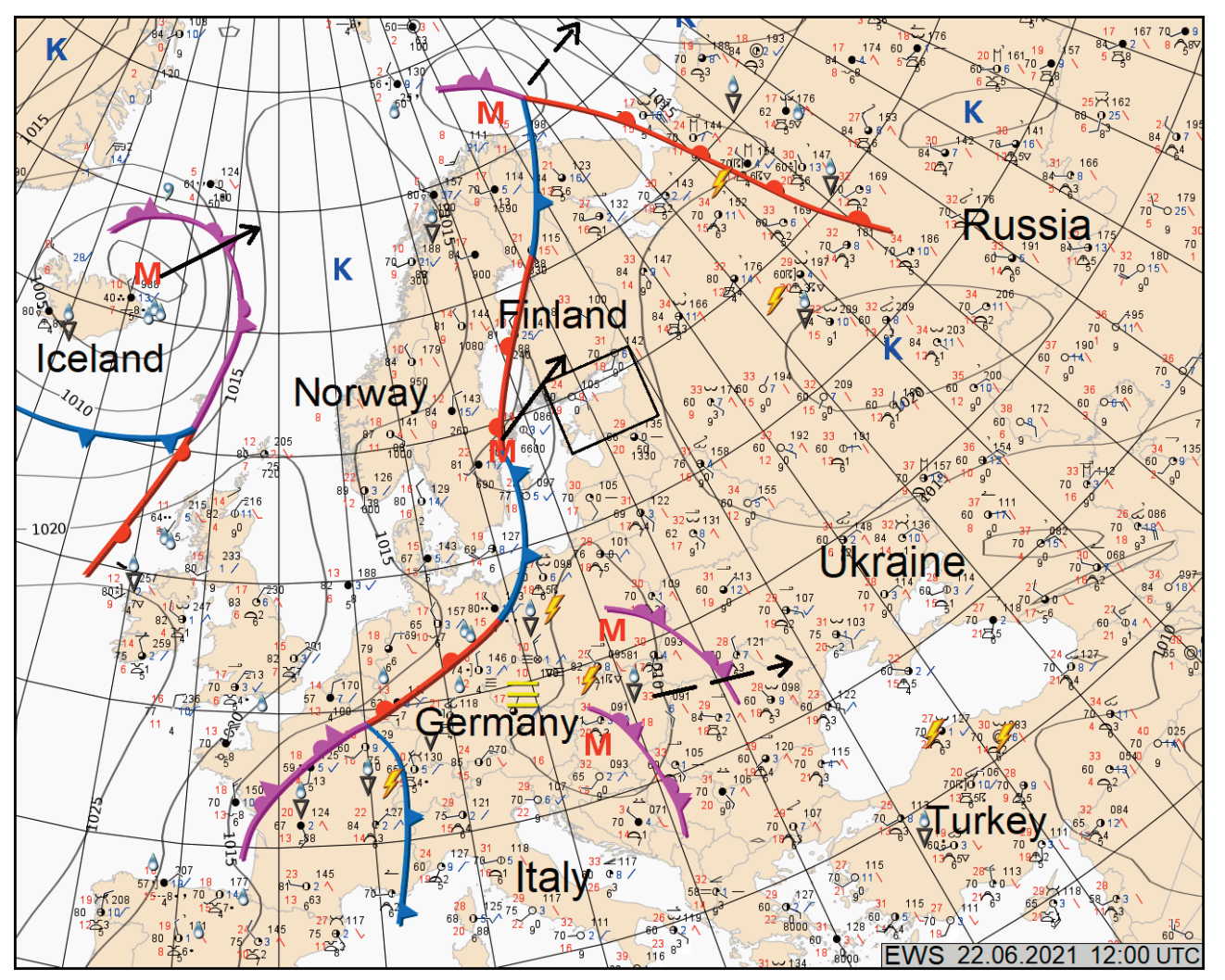

Fig. 4. A weather forecast map fragment (courtesy of the EWS) illustrating meteorological conditions together with high (K) and low (M) pressure systems during the heat wave on 22 June 2021. On 23 June, record-breaking air temperatures in Estonia were registered; thereafter, a front from the weak low-pressure system (centre near Stockholm) crossed Estonia and ended the heat wave episode by 24 June (see Fig. 5). Arrows indicate movements of the lows over 24 h (by 23 June); dashed arrows - dissipation of the cyclones. The study area is marked with a rectangle. 

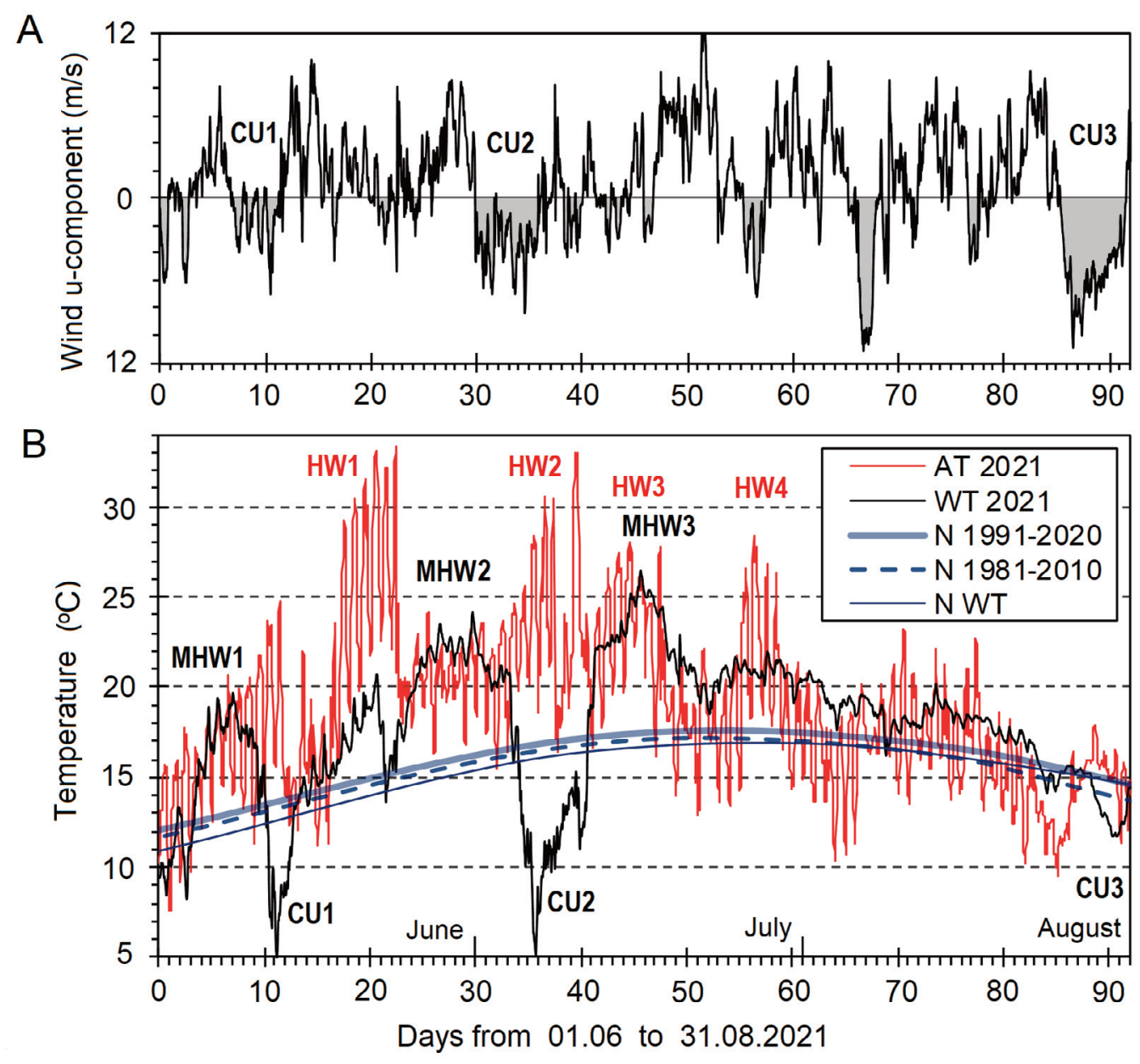

Fig. 5. A, variations in the wind velocity $u$-component (E direction positive) at the Kunda station. B, variations in air (AT) and water (WT) temperatures at the Kunda station in summer 2021 together with long-term norms in air temperatures (N 1991-2020, N 19812010; interpolated EWS data) and Kunda water temperatures (N WT, interpolated data from Astok \& Mardiste 1995). Heat wave (HW), marine heat wave (MHW) and coastal upwelling (CU) episodes are marked on the graphs.

Table 1. The HW (Kunda weather station) and MHW (Kunda coastal station) events in 2021. Air (AT) or water (WT) temperatures $\left({ }^{\circ} \mathrm{C}\right)$ : M24 - maximum 24-h average, M1 - maximum 1-h average, AM - absolute maximum. Numbers of consecutive days: $>\left(\mathrm{N}+5^{\circ}\right)-24$-h average AT at least $5^{\circ} \mathrm{C}$ above norm $(1991-2020)$; $*$ in the case of MHWs, 24-h average WT was at least $5.5^{\circ} \mathrm{C}$ above the historical norm; AM $>30$ and AM $>27$ - daily absolute AT maxima over $30^{\circ} \mathrm{C}$ and $27^{\circ} \mathrm{C}$, respectively; WM $>22$ - maximum water temperature over $22^{\circ} \mathrm{C}$

\begin{tabular}{l|c|c|c|c|c|c|c|c}
\hline \multicolumn{2}{c}{ Event } & \multicolumn{3}{c|}{ Temperature $\left({ }^{\circ} \mathrm{C}\right)$} & \multicolumn{4}{c}{ Number of consecutive days } \\
\hline Code & Period & M24 & M1 & AM & $>\left(\mathrm{N}+5^{\circ}\right)$ & AM $>30$ & AM $>27$ & WM $>22$ \\
\hline HW1 & $18.06-23.06$ & 28.3 & 33.3 & 34.1 & 6 & 5 & 6 & - \\
HW2 & $04.07-10.07$ & 27.8 & 33.0 & 33.9 & $5+1$ & $2+1$ & $3+1$ & - \\
HW3 & $13.07-18.07$ & 25.0 & 28.0 & 29.1 & 5 & 0 & $3+1$ & - \\
HW4 & $27.07-29.07$ & 24.1 & 28.4 & 29.5 & 1 & 0 & 3 & - \\
MHW1 & $06.06-09.06$ & 18.3 & 19.7 & - & $4 *$ & - & - & 0 \\
MHW2 & $25.06-01.07$ & 22.5 & 24.2 & - & $7^{*}$ & - & - & 6 \\
MHW3 & $14.07-18.07$ & 25.4 & 26.5 & - & $5^{*}$ & - & - & 9 \\
\hline
\end{tabular}


4-10 July. At the same time, water temperature was only about $5-12{ }^{\circ} \mathrm{C}$ at the nearby Kunda marine station (Fig. 5B). The upwelling (CU2) was caused by easterly winds (Fig. 5A) on 1-7 July, which is a typical course of actions in this part of the sea (Suursaar 2010). The upwelling was preceded and followed by two MHWs (MHW2 and MHW3, respectively). Therefore, a noticeable change in water temperature (of $19.1^{\circ} \mathrm{C}$, from 24.2 to $5.1^{\circ} \mathrm{C}$ by 6 July) occurred within $144 \mathrm{~h}$ (6 days), and a $21.4^{\circ} \mathrm{C}$ rise (from 5.1 to $26.5^{\circ} \mathrm{C}$ by 17 July) took place within 10 days. The prominent MHW3 was accompanied by the atmospheric HW3 (Fig. 5B; Table 1). The event HW4 did not qualify as a proper HW, as only 1-3 days (depending on criteria) exceeded the required limits (Table 1).

It is interesting to note that HWs and MHWs did not coincide with each other at Kunda. Apparently, the stable anticyclone weather pattern, which is needed for an HW, gradually starts hampering an MHW with upwelling. Although bringing along very warm air masses from the east or southeast, the easterlies are also upwellingfavourable along the North Estonian coast. The evolvement of upwelling usually lags for 2-3 days, until the cooler water from the deep sea reaches surface. The needed wind impulse increases through summer, as the upper (warmed-up), mixed layer gets thicker (Haapala 1994). For instance, a prolonged easterly wind episode in August (CU3; Fig. 5) had a much smaller impact on water temperature than the earlier CU1 and CU2 had.

\section{MHW in the Gulf of Finland in 2021}

At the GWB, in the open part of the gulf, $18{ }^{\circ} \mathrm{C}$ was exceeded for the first time on 18 June, and the water temperature gradually rose during a month (Fig. 6F). The highest ever (over the period 2004-2021) water temperature, $26.6^{\circ} \mathrm{C}$, was measured on 14 July 2021 . The 24-h average reached $25.2^{\circ} \mathrm{C}$ both on 14 and 15 July and $25.5^{\circ} \mathrm{C}$, over the 24 -h period between 08 AM 14 July and 08 AM 15 July (Table 2). At the Kotka buoy, the hourly

Table 2. Characteristics and ranking of the summer HWs and MHWs in the Gulf of Finland area; daily maximum air temperatures and the number of days with maxima over $26^{\circ} \mathrm{C}$ at the HLS, PKS and KHS (see Fig. 1 for station codes); maximum air temperatures at the PH, KA, KS, TS and NS. Absolute maximum water temperatures (SST), maximum 24-h averages and integral values (int; in degree-hours) over the bases of 18,20 and $22^{\circ} \mathrm{C}$ calculated at the GWB, HB and KB. Based on rankings of individual characteristics, the aggregate ranks (for HW, MHW) are (somewhat subjectively) grouped and presented

\begin{tabular}{llllllll|l}
\hline \multicolumn{1}{c}{ Characteristic } & \multicolumn{1}{c}{2021} & \multicolumn{1}{c}{2010} & \multicolumn{1}{c}{2018} & \multicolumn{1}{c}{2014} & \multicolumn{1}{c}{2011} & \multicolumn{1}{c}{2019} \\
\hline HLS max air & 29.2 & 28.0 & - & 26.8 & 25.0 & 27.2 \\
HLS days $>26^{\circ}$ & 8 & 5 & - & 3 & 0 & 1 \\
PKS max air & 29.0 & 29.4 & 26.6 & 26.9 & 25.7 & - \\
PKS days $>26^{\circ}$ & 7 & 6 & 4 & 3 & 0 & - \\
KHS max air & 30.4 & 29.1 & 31.3 & 28.3 & 29.1 & 31.2 \\
KHS days $>26^{\circ}$ & 7 & 7 & 6 & 2 & 3 & 3 \\
PH max air & 32.0 & 32.6 & 31.2 & 31.2 & 31.3 & 33.1 \\
KA max air & 32.7 & 33.5 & 32.1 & 32.1 & 31.3 & 32.5 \\
KS max air & 34.1 & 34.4 & 32.6 & 32.3 & 31.7 & 29.5 \\
TS max air & 32.6 & 32.3 & 34.2 & 32.0 & 31.2 & 31.6 \\
NS max air & 34.6 & 35.4 & 31.9 & 31.9 & 31.7 & 30.3 \\
\hline GWB max SST & 26.6 & 23.9 & 25.5 & 25.4 & 24.1 & 23.8 \\
HB max SST & 25.3 & - & 26.1 & 25.7 & - & 22.2 \\
KB max SST & 27.9 & - & 25.9 & - & - & 21.3 \\
GWB max 24-h average & 25.5 & 22.4 & 24.3 & 24.4 & 22.4 & 22.3 \\
(date) & $(14 / 15.07)$ & $(2 / 3.08)$ & $(25 / 26.07)$ & $(27 / 28.07)$ & $(27 / 28.07)$ & $(27 / 28.07)$ \\
HB max 24-h average & 25.0 & - & 24.2 & 24.6 & - & 20.2 \\
(date) & $(15 / 16.07)$ & & $(2 / 3.08)$ & $(27.07)$ & & $(28 / 29.07)$ \\
GWB int $>18^{\circ}$ & 2648 & 3205 & 2319 & 2377 & 1983 & 574 \\
GWB int $>20^{\circ}$ & 1149 & 1048 & 1018 & 1110 & 322 & 97 \\
GWB int $>22^{\circ}$ & 364 & 29 & 272 & 280 & 16 & 15 \\
\hline HW rank & $\mathbf{1 - 2}$ & $\mathbf{1 - 2}$ & $\mathbf{3}$ & $\mathbf{4}$ & $\mathbf{5 - 6}$ & $\mathbf{5 - 6}$ \\
MHW rank & $\mathbf{1}$ & $\mathbf{2 - 4}$ & $\mathbf{2 - 4}$ & $\mathbf{2 - 4}$ & $\mathbf{5}$ & $\mathbf{6}$ \\
\hline
\end{tabular}



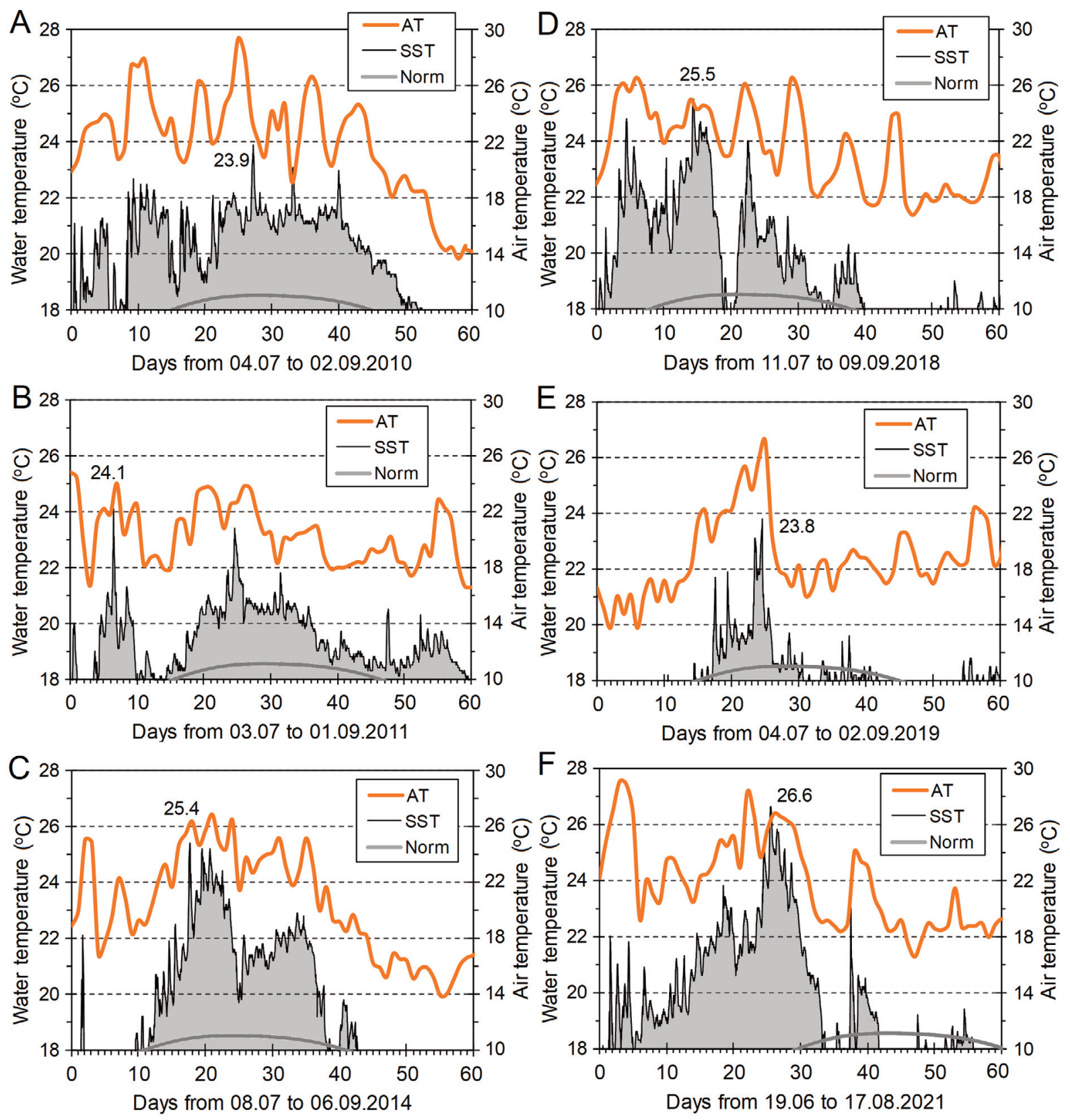

Fig. 6. Comparison of time series of air temperatures (AT; at the Porvoo Kalbådagrund station - PKS) and water temperatures (SST; at the Gulf of Finland wave buoy - GWB) together with the GWB 'norm' (2005-2021 average) in selected years. Annual SST peak values are indicated on graphs. The series begin when SST exceeds $18{ }^{\circ} \mathrm{C}$ for the first time (except in $\mathbf{E}$ ) and spans equally for 60 days. Grey fill (integral) over the $18{ }^{\circ} \mathrm{C}$ base illustrates aspects of both the duration and magnitude of the MHWs and helps to compare the events. As the PKS data are missing for 2019, AT data from the nearby Helsinki Lighthouse are used in (E).

maximum was $27.9^{\circ} \mathrm{C}$ (on 14 July) and the maximum 24-h average reached $25.8^{\circ} \mathrm{C}$ ( 15 July), the highest on record, too. However, within the next few days, westerly winds brought cooler air masses and also initiated an upwelling along the Finnish coast. Consequently, after the spatially rather homogeneous period (Fig. 7A), the SST variation range over the Gulf of Finland increased, becoming ca $13-23{ }^{\circ} \mathrm{C}$ on 25 July (Fig. 7B). The massive upwelling along the Finnish coast largely eroded the MHW and the weather in August was not very hot.

Water temperatures at coastal stations may considerably deviate from temperatures in the open part of 


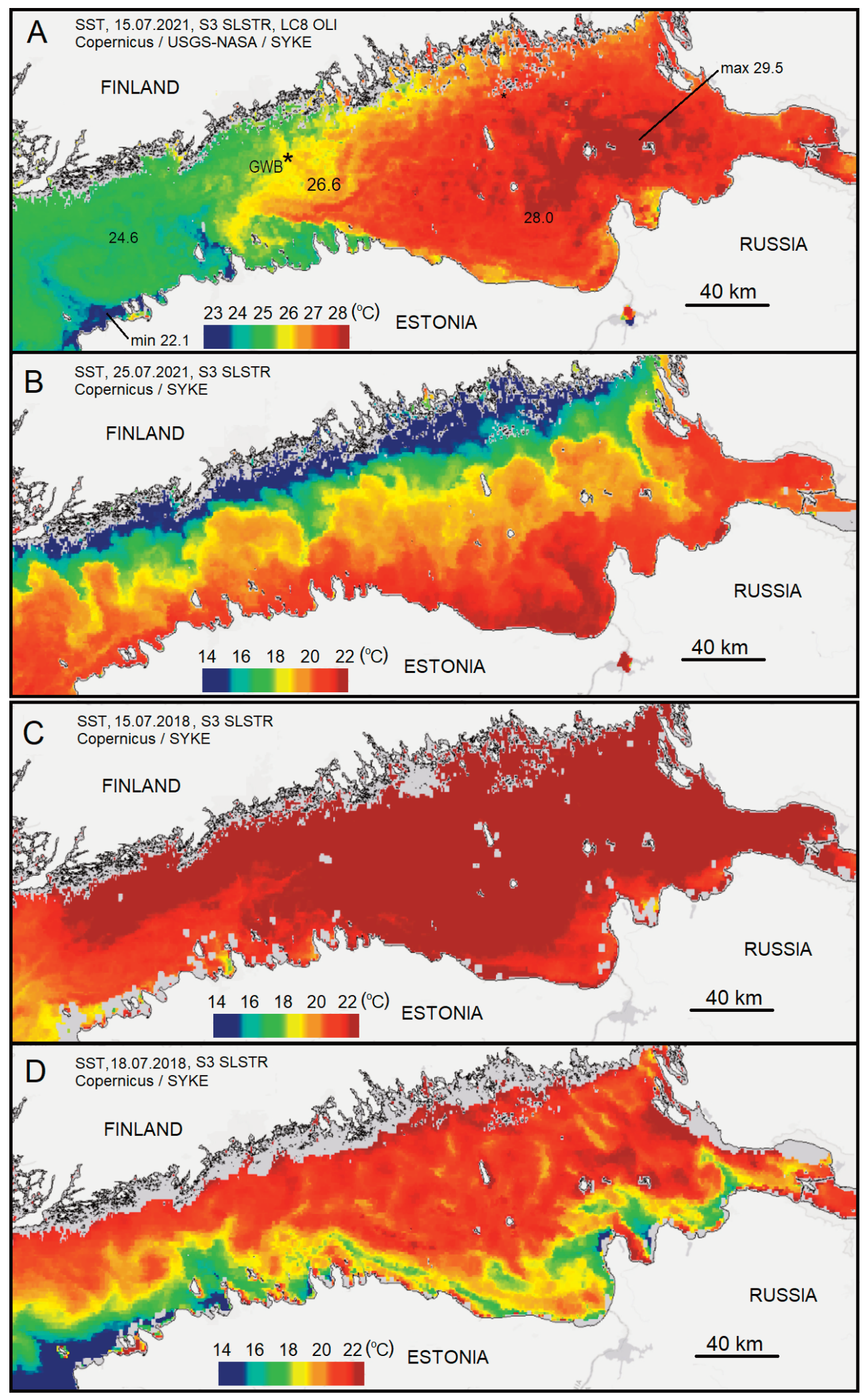

Fig. 7. SST images (modified from SYKE TARKKA) during the MHW peak in the Gulf of Finland on 15 July 2021 (A), subsequent CU at the Finnish coast on 25 July 2021 (B); MHW on July 2018 (C) and its erosion due to CU along the North Estonian coast (D). Note the different SST scales (e.g. $23-29^{\circ} \mathrm{C}$ in A). Grey areas on the sea are clouds. 
the gulf, mainly due to CUs (e.g. Fig. 5B vs 6F), occurring either on the Finnish side (with westerlies) or Estonian side (with easterlies). Therefore, it is interesting to estimate the average SST over the Gulf of Finland during the peak MHW. An analysis of SST data from 15 July presented by SYKE TARKKA (Fig. 7A) revealed a maximum of around $29.5^{\circ} \mathrm{C}$ in the middle of the eastern Gulf of Finland (at $60.05^{\circ} \mathrm{N}$ ) near Seskar Island. The calculated average over the limits of the Gulf of Finland was $26.3^{\circ} \mathrm{C}$ $\left( \pm 1{ }^{\circ} \mathrm{C}\right)$. Such an extremely high basin-wide value appeared due to the strong $\mathrm{HW}$, and relatively uniform distribution of high water temperatures across the entire gulf: at the peak of the event, no substantial upwelling occurred on either coast. The reliability of this $26.3^{\circ} \mathrm{C}$ estimate can be provisionally assessed by comparing the simultaneous values from the GWB series and on the SST image. Despite the normal, $\mathrm{ca} 1^{\circ} \mathrm{C}$ diurnal variation range and slightly different sampling depths $(20 \mathrm{~cm}$ depth at buoy versus the surface film sampled by a radiometer), the in situ (24.9-25.8 $\left.{ }^{\circ} \mathrm{C}\right)$ and remotely sensed readings $\left(25.5^{\circ} \mathrm{C}\right)$ matched very well indeed at that point (Fig. 7A). However, as it was briefly discussed in the 'Material and methods' section, up to $\pm 0.5^{\circ} \mathrm{C}$ errors in SST processing, as well as biases between remotely sensed, measured or modelled SST data, may occur (Konik et al. 2019; Zujev et al. 2021). Therefore, it is advisable to recalculate this gulf-wide average by using different approaches (e.g. numerical modelling). These may yield not necessarily 'more correct' results, but just slightly different ones.

The highest water temperature zone was in the eastern half of the gulf (Fig. 7A). The minimum $22.1^{\circ} \mathrm{C}$ occurred in the near-coastal grid-cells in the southeastern part of the gulf between Dirhami and Paldiski (Fig. 1). Although the coastal stations by the EWS registered $14{ }^{\circ} \mathrm{C}$ (e.g. at the Paldiski station), these values only represented a narrow nearshore strip and showed the influence of a weak, non-influential upwelling. The easterly winds were too weak to allow the formation of more influential upwelling. At the same time, the eastern section of the North Estonian coast was not affected by that upwelling at all, as the SST reached at least $28.1^{\circ} \mathrm{C}$ on two consecutive days (15 and 16 July) at the Narva-Jõesuu coastal station. Although the Narva River waters can affect the water temperature readings at this station, the SST values in the entire eastern Gulf of Finland were similarly high in these days indeed (Fig. 7A).

\section{Sequential interaction between HWs, MHWs and CUs}

The interaction between HWs, MHWs and CUs in the Gulf of Finland can be very fascinating. Firstly, SST contrasts between the MHW and CU influenced parts of the gulf may reach as much as $20^{\circ} \mathrm{C}$. This occurred during the 2014 HW (Suursaar 2020). While total SST ranges, both spatial and temporal ones, were over $20^{\circ} \mathrm{C}$, a $17.1^{\circ} \mathrm{C}$ SST drop occurred within $50 \mathrm{~h}$ at the Kunda station, and a $15.7^{\circ} \mathrm{C}$ drop occurred within $24 \mathrm{~h}$ at the RDCP mooring location near the Letipea Peninsula in 2014. As demonstrated above, a $21.4{ }^{\circ} \mathrm{C}$ rise (from 5.1 to $26.5^{\circ} \mathrm{C}$ by 17 July) occurred at Kunda within 10 days during the 2021 event. Repetitive alteration between the MHWs and CUs was also registered in 2006 (Fig. 8; Suursaar \& Aps 2007; Lips et al. 2009). Upwelling in the Baltic Sea can form thermohaline fronts that are much stronger than other kind of fronts in the same area (Suursaar et al. 2021). Quantification of maximum spatial SST differences through the front requires cloud-free SST images or modelling. Up to $\mathrm{ca} 10^{\circ} \mathrm{C}$ contrasts are relatively frequently recorded in the Gulf of Finland (e.g. Soomere et al. 2008; Lips et al. 2009; Uiboupin \& Laanemets 2009). Considering low CU-related summer-time water temperatures (e.g. at Kunda, $4.7{ }^{\circ} \mathrm{C}$ in 2014 and $4.9^{\circ} \mathrm{C}$ in 2021) and MHW maxima $\left(26-29^{\circ} \mathrm{C}\right.$ in the Gulf of Finland in 2021), about 21-22 ${ }^{\circ} \mathrm{C}$ SST differences might be possible.

While the MHWs are caused by hot continental (Asian) air mass sustained by a stable anti-cyclonic weather pattern and relatively calm wind conditions (e.g. She et al. 2020), their end (besides gradual, seasonal cooling) may basically occur in two ways. Firstly, this happens by the increasing prevalence of an atmospheric westflow, which brings along cooler (North Atlantic) air masses and stronger winds that stimulate water column mixing and also create upwelling along the Finnish coast (Fig. 7B).

Secondly, the easterly winds on the margin area of the anticyclone that governs the MHW intensify and eventually cause a major, long-lasting upwelling along the Estonian coast (Fig. 7D). The upwelled cold $\left(3-5^{\circ} \mathrm{C}\right)$ water can gradually spread over $c a 1 / 3$ of the gulf's surface area (Uiboupin \& Laanemets 2009). Although the MHW may endure over the northern part of the gulf, it shrinks and loses its impact. This kind of sequence of events has happened quite often. The MHW stays longer when easterly winds stay relatively weak. Thus, while an HW primarily contributes to the evolvement of the MHW, the very same stable anticyclone weather pattern that is needed for the HW, may evoke the CU, which in turn starts to erode the MHW from the south. Although the occurrence of the CU can be guessed on the basis of low water temperatures, the simultaneous, registered increase in salinity indicates that e.g. a lateral advection is not the case (Suursaar 2021). Swift water temperature and salinity variations, negatively correlated to each other (Fig. 9), are very typical for CUs in the southern part of the Gulf of Finland. As the North Estonian coastline somewhat bends, small variations in wind direction cause the upwelling zone to swing east- and westwards (Fig. 8). For instance, for the Dirhami region, the most upwelling-favourable 


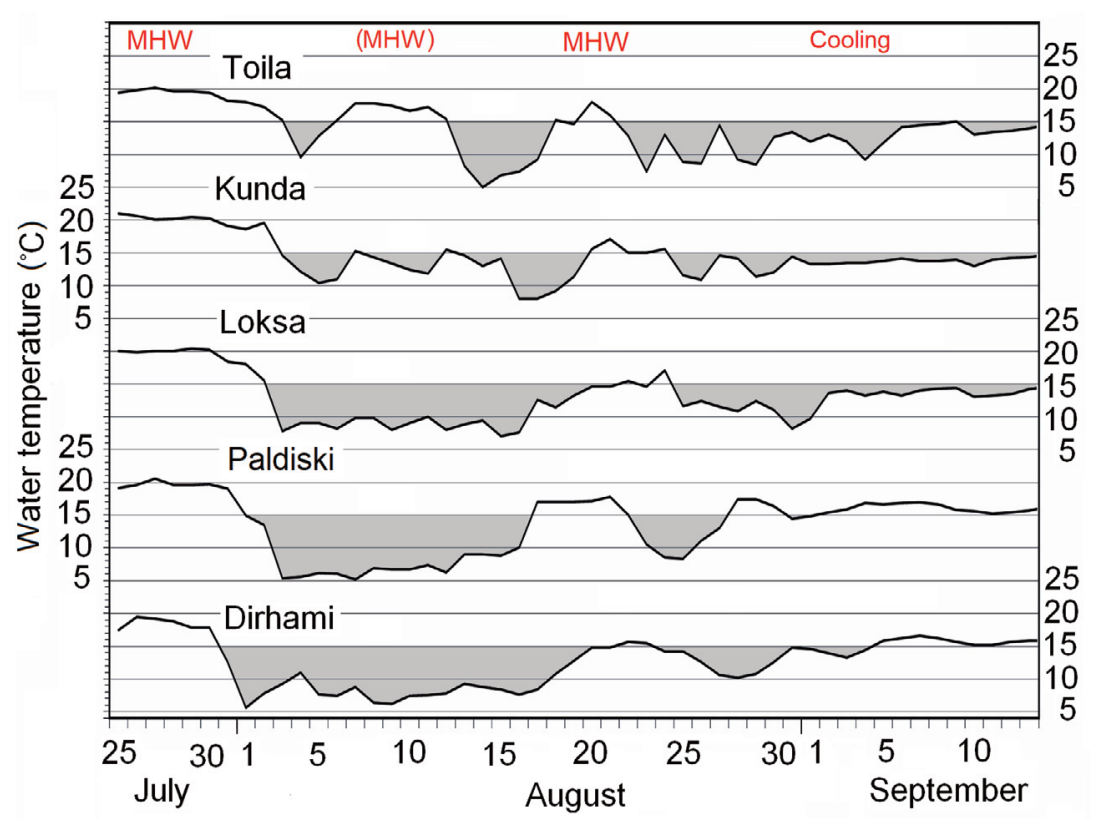

Fig. 8. Example of variations in water temperature at marine stations (by the EWS) along the northern coast of Estonia (see Fig. 1) between 25 July and 14 September 2006 (modified from Suursaar \& Aps 2007). The grey areas indicate CUs (temperatures $<15^{\circ} \mathrm{C}$ ) occurring between the MHWs.

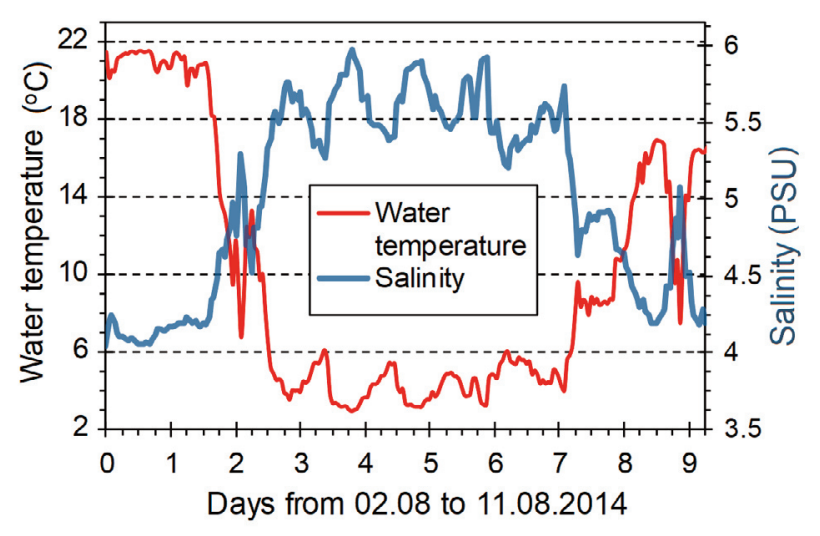

Fig. 9. Example of contrasting variations in water temperature and salinity indicating upwelling (low temperature, high salinity) recorded with the RDCP at $10 \mathrm{~m}$ depth near the Letipea Peninsula (see also Suursaar 2020).

wind direction is from the northeast, while for the KundaLetipea section it is from the east or southeast.

Depending on the dominant wind pattern (either westerlies or easterlies), the erosion of an MHW event can occur either on the northern side of the Gulf of Finland (Fig. 7B) or on its southern side (Fig. 7D), respectively. Moreover, in an elongated estuary like the gulf, upwelling on one coast is usually paired with downwelling on the opposite coast (e.g. Zhurbas et al. 2008; Suursaar 2020). It has been argued that while the cooling effect of the CUs may occasionally mitigate the overheating effects by the HWs both in the sea and on the sea-land boundary, the simultaneously or subsequently occurring HWs and upwellings/downwellings in the Gulf of Finland may effectively contribute to heat transfer from the atmosphere down to the water mass (Suursaar 2020). Hence, CUs actually do not counteract MHWs, or perhaps, do it in only local ecological terms (Paalme et al. 2020).

\section{Comparison and ranking of the years}

Table 2 and Fig. 6 summarize the most remarkable events (years) over the last 11 years. In fact, 2000-2009 only had a few, less influential HWs (e.g. in 2003 and 2006), which did not rank among the most extreme ones in 20102021. The life cycles of the MHWs have been rather different (Fig. 6). Although some HWs can already occur in June, MHWs usually start in July, due to larger inertia of thermal processes in an aquatic environment. An exception was 2021, when the MHW began in the middle of June (Figs 5B, 6F).

According to maxima, the most extreme MHW events were in 2021 (Table 2), followed by 2018 and 2014. The 'norm' of 2005-2021 was exceeded by 5-8 degrees in those years (and would have been exceeded even more if a proper, historical 'norm' had been available). However, the summer of 2010 stood out because of the extremely long duration of the MHW. The 'sum of active temperatures' approach enabled comparison of those very different 
events. The area (integral) of such temperatures relative to the $18{ }^{\circ} \mathrm{C}$ basis is shown with grey shade in Fig. 6 . According to that, the MHW ranking would be 2010, 2021, 2014, 2018, 2011 and 2019 (Table 2). If the comparison was based on the $20{ }^{\circ} \mathrm{C}$ threshold, the ranking would be 2021, 2014, 2010, 2018, 2011 and 2019. The $22^{\circ} \mathrm{C}$ threshold would give the following ranking: 2021, 2014 and 2018, followed by 2010, 2011 and 2019 with minuscule sums.

Covering large portions of Russia, but also Ukraine, Belarus and the Baltic States, the 2010 event was so huge in areal extent and high temperatures stayed for so long that analogues of such an HW were then considered unlikely to happen in the next few decades (Barropedro et al. 2011). Yet, the 2021 event seems to be at least equal to it, although covering somewhat different geographical areas. In fact, the temperature $48.8{ }^{\circ} \mathrm{C}$ was measured on 11 August 2021 in Syracuse, Italy, which was verified by the WMO as the highest known temperature ever recorded in Europe (Le Page 2021).

When combining various characteristics of HWs and MHWs, the years 2021 and 2010 probably are a 'tie' in terms of the HW, followed by 2018 and 2014. The years 2011, 2019 and the others clearly rank behind. In terms of the MHW, 2021 is the first, followed nearly equally by 2014, 2010 and 2018. Again, 2011 and 2019 rank behind. In addition to those listed in Table 2, the summer of 2003 had maximum air temperatures of $29.9{ }^{\circ} \mathrm{C}$ at the KHS, $27.9^{\circ} \mathrm{C}$ at the PKS and $27.6^{\circ} \mathrm{C}$ at the HLS. Meteorologically, the year 2003 (see also Figs 2B, 3B) could rank close to 2011 and 2014, probably in $\mathrm{ca}$ 4th-6th place over the period from 2000 to 2021 (see also Ruuhela et al. 2021), but this year is not sufficiently covered by the SST data sets used in this study. The summer of 2006 (Figs 3B, 8) was hot, too, but still not as hot as the other studied summers.

It should be kept in mind that a different choice of stations and assessment criteria would have given, perhaps, slightly different results. For instance, MHW imprints in the coastal sea are influenced by 'swinging' CUs (Fig. 8). However, the geographical scale of HW events is around $1000 \mathrm{~km}$ and more, and the events highlighted in this study (e.g. 2010, 2014, 2018 and 2021) have been considered in many previous studies on the region of the Baltic Sea and northern Europe. It is very likely that the years 2021 and 2010 indeed had the most influential HWs and MHWs known in the Gulf of Finland. As the climate in the Baltic region has warmed by $1-2{ }^{\circ} \mathrm{C}$ over the last thirty years (CMEMS 2021a), and up to ca $2{ }^{\circ} \mathrm{C}$ over the last century (e.g. Rutgersson et al. 2015), it is unlikely that any other year has seen HWs that exceeded the ones in 2021 and 2010. It is even more so in the case of MHWs, because of slowly accumulating heat content and inertia in aquatic environments (e.g. Cheng et al. 2020).

\section{CONCLUSIONS}

1. The summer of 2021 (June, July, August) was the hottest on record in Estonia with the country-wide average temperature of $18.6^{\circ} \mathrm{C}$ and the Kunda station average of $18.8^{\circ} \mathrm{C}$. According to the more closely studied Kunda air and sea surface temperatures, three distinct HW episodes (with at least 5-day duration) were identified: on $18-23$ June $\left(\max 34.1^{\circ} \mathrm{C}\right), 4-10$ July ( $\max 33.9^{\circ} \mathrm{C}$ ) and 13-18 July, and one less distinct episode on 27-29 July. Also, three episodes of high water temperatures (MHWs) occurred on 6-9 June, 25 June to 1 July, and 14-18 July. The maximum SST of $26.5^{\circ} \mathrm{C}$ was registered at the Port of Kunda on 16 July, whereas $28.1{ }^{\circ} \mathrm{C}$ was registered at NarvaJõesuu on two consecutive days on 15-16 July. Although the HWs extend over large (order of $1000 \mathrm{~km}$ or more) areas, the exact periods and specific characteristics of HWs and MHWs may slightly vary by area and station-wise. The HWs and MHWs were not entirely synchronous to each other because of the interrupting influence of three coastal upwelling episodes with minimum water temperatures of $4.9^{\circ} \mathrm{C}$ on 11 June and $5.1^{\circ} \mathrm{C}$ on 6 July.

2. In parallel with high air temperatures, a recordbreaking MHW occurred in the open part of the Gulf of Finland. According to the measurements at Finnish buoy stations in the open part of the gulf, SST reached $27.9^{\circ} \mathrm{C}$ at the Kotka station and $26.6^{\circ} \mathrm{C}$ at the Gulf of Finland wave buoy (GWB); the maximum 24-h average of $25.5{ }^{\circ} \mathrm{C}$ was recorded at the GWB (all highest on corresponding records). According to preliminary analysis of SST satellite images, the gulfwide average SST was $26.3^{\circ} \mathrm{C}\left( \pm 1 \mathrm{C}^{\circ}\right)$ at its peak moment on 15 July with a local maximum around $29.5^{\circ} \mathrm{C}$ in the gulf's eastern part near Seskar Island. However, on calm sunny days, the remotely sensed SST values can be somewhat higher than the in situ observed or modelled ones.

3. Like many other MHWs, the year 2021 event was interrupted and finally terminated by CUs. While the MHWs mainly occur due to hot continental (Asian) air masses sustained by a stable anti-cyclonic weather pattern and relatively calm wind conditions, their destruction (besides gradual, seasonal cooling) may basically occur in two ways. Firstly, by the gaining prevalence of atmospheric westflow, which brings along cooler North Atlantic air masses and stronger winds that stimulate water column mixing and also evoke upwelling along the Finnish coast. Secondly, the very same stable anticyclone weather pattern, which is needed for the HW, gradually starts to erode the MHW along the Estonian coast with upwelling. Although bringing along very warm air masses from 
the south or east, the easterly is also an upwellingfavourable forcing along the North Estonian coast.

4. A comparison of summers with the most influential HWs and MHWs in the region of the Gulf of Finland over 2010-2021 suggested the aggregate rankings provided below. In terms of HWs, the summers of 2021 and 2010 were more or less a tie, followed by 2018, 2014, 2011 and 2019. In the MHW ranking, the summer of 2021 clearly included the most influential MHW events, followed (tied) by 2014, 2010 and 2018, and then by 2011 and 2019. Meteorologically, also 2003 could have ranked in $c a$ 4th-6th place. Because of the clear warming trend in the Baltic Sea area over the last 50-60 years, it is extremely unlikely that any other summer from earlier periods could have been warmer and included more influential HWs and MHWs than 2021 and 2010 did, especially in the case of MHWs, because of slowly accumulating heat content and inertia in aquatic environments.

Acknowledgements. We are grateful to the Estonian Weather Service (EWS) for the Estonian weather and coastal marine data, Finnish Meteorological Institute for the Finnish meteorological and hydrological data and Finnish Environment Institute for the pre-processed SST images of the Gulf of Finland. Helve Meitern from the EWS is acknowledged for helping with the weather maps. We also thank the referee Jaan Laanemets and an anonymous referee for their suggestions on the manuscript. The study was supported by the Estonian Research Council grant PRG1471. The publication costs of this article were partially covered by the Estonian Academy of Sciences.

\section{REFERENCES}

Armstrong, B. 2006. Models for the relationship between ambient temperature and daily mortality. Epidemiology, 17, 624-631.

Astok, V. \& Mardiste, H. 1995. Contemporary sea. In Eesti. Loodus [Estonia. Nature] (Raukas, A., ed), pp. 228-237. Valgus, Tallinn [in Estonian].

Barriopedro, D., Fischer, E. M., Luterbacher, J., Trigo, R. M. \& Garcia-Herrera, R. 2011. The hot summer of 2010: redrawing the temperature record map of Europe. Science, 332, 220-224.

Beniston, M., Stephenson, D. B., Christensen, O. B., Ferro, C. A. T., Frei, C., Goyette, S., Halsnaes, K., Holt, T., Jylhä, K., Koffi, B., Palutikof, J., Schöll, R., Semmler, T. \& Woth, K. 2007. Future extreme events in European climate: an exploration of regional climate model projections. Climatic Change, $\mathbf{8 1}$, 71-95.

Cheng, L., Abraham, J., Zhu, J., Trenberth, K. E., Fasullo, J., Boyer, T., Locarnini, R., Zhang, B., Yu, F., Wan, L., Chen, X., Song, X., Liu, Y. \& Mann, M. E. 2020. Record-setting ocean warmth continued in 2019. Advances in Atmospheric Sciences, 37, 137-142.
CMEMS. 2021a. Baltic Sea Anomaly Time Series of Sea Surface Temperature. https://marine.copernicus.eu/access-data/oceanmonitoring-indicators/baltic-sea-anomaly-time-series-sea-su rface-temperature [accessed 18 October 2021].

CMEMS. 2021b. Copernicus: Warmest Summer for Europe by Small Margin; August Globally Joint Third Warmest on Record. Press Release, 7th September 2021. https://climate.copernicus.eu/copernicus-warmest-summereurope-small-margin-august-globally-joint-third-warmest-re cord [accessed 18 October 2021].

Easterling, D. R., Meehl, G. A., Parmesan, C., Changnon, S. A., Karl, T. R. \& Mearns, L. O. 2000. Climate extremes: observations, modeling, and impacts. Science, 289, 20682074.

EWS. 2021a. Riigi Ilmateenistus. Suvi 2021 [Estonian Weather Service. Summer 2021]. https://storymaps.arcgis.com/stories/ 8bc2e0cbf0944eccb5802deefd4d782f [in Estonian, accessed 18 October 2021].

EWS. 2021b. Estonian Weather Service. Coastline stations. http://www.ilmateenistus.ee/meri/vaatlusandmed/kogu-rannik/ kaart/?lang=en [accessed 18 September 2021].

EWS. 2021c. Riigi Ilmateenistus. Ajaloolised ilmaandmed [Estonian Weather Service. Historical data]. http://www. ilmateenistus.ee/kliima/ajaloolised-ilmaandmed/ [in Estonian, accessed 18 October 2021].

FMI. 2021. Finnish Meteorological Institute. Download observations. https://en.ilmatieteenlaitos.fi/download-observations [accessed 18 October 2021].

Haapala, J. 1994. Upwelling and its influence on nutrient concentration in the coastal area of the Hanko Peninsula, entrance of the Gulf of Finland. Estuarine, Coastal and Shelf Science, 38, 507-521.

Hobday, A. J., Oliver, E. C. J., Sen Gupta, A., Benthhuysen, J. A., Burrow, M. T., Donat, M. G., Holbrook, N. J., Moore, P. J., Thomsen, M. S., Wernberg, T. \& Smale, D. A. 2018. Categorizing and naming marine heatwaves. Oceanography, 31(2), 162-173.

Høyer, J. \& Karagali, I. 2016. Sea surface temperature climate data record for the North Sea and Baltic Sea. Journal of Climate, 29, 2529-2541.

IPCC. 2014. IPCC Fifth Assessment Report (AR5). https://www. ipcc.ch/report/ar5/

Keevallik, S. \& Vint, K. 2012. Influence of changes in the station location and measurement routine on the homogeneity of the temperature, wind speed and precipitation time series. Estonian Journal of Engineering, 18, 302-313.

Keevallik, S. \& Vint, K. 2015. Temperature extremes and detection of heat and cold waves at three sites in Estonia. Proceedings of the Estonian Academy of Sciences, 64, 473479.

Konik, M., Kowalewski, M., Bradtke, K. \& Darecki, M. 2019. The operational method of filling information gaps in satellite imagery using numerical models. International Journal of Applied Earth Observation and Geoinformation, 5, 68-82.

Kont, A., Endjärv, E., Jaagus, J., Lode, E., Orviku, K., Ratas, U., Rivis, R., Suursaar, Ü. \& Tõnisson, H. 2007. Impact of climate change on Estonian coastal and inland wetlands - a summary with new results. Boreal Environment Research, 12, 653-671. 
Le Page, M. 2021. Sicily hits $48.8^{\circ} \mathrm{C}$, the highest temperature ever recorded in Europe. New Scientist. 12 August 2021.

Lhotka, O., Kyselý, J. \& Farda, A. 2018. Climate change scenarios of heat waves in Central Europe and their uncertainties. Theoretical and Applied Climatology, 131, 1043.

Lips, I., Lips, U. \& Liblik, T. 2009. Consequences of coastal upwelling events on physical and chemical patterns in the central Gulf of Finland (Baltic Sea). Continental Shelf Research, 29, 1836-1847.

Minnett, P. J., Alvera-Azcárate, A., Chin, T., Corlett, G., Gentemann, C., Karagali, I., Li, X., Marsouin, A., Marullo, S., Maturi, E., Santoleri, R., Saux Picart, S., Steele, M. \& Vazquez-Cuervo, J. 2019. Half a century of satellite remote sensing of sea-surface temperature. Remote Sensing of Environment, 233, 111366.

Näyha, S. 2007. Heat mortality in Finland in the 2000s. International Journal of Circumpolar Health, 66, 418-424.

NOAA. 2021. Global Climate Report - Annual 2020. https://www.ncdc.noaa.gov/sotc/global/202013 [accessed 18 October 2021].

Õispuu, T.-M. 2019. Heat waves in Estonia in 1951-2018. In Yearbook of Estonian Geographical Society, Vol. 44 (Järvet, A., ed), pp. 93-110. Tallinn. http://egs.ee/wpcontent/uploads/2019/12/EGS_Aastaraamat_44kd.pdf [in Estonian, with English summary; accessed 18 October 2021].

Oliver, E. C. J., Burrows, M. T., Donat, M. G., Sen Gupta, A., Alexander, L. V., Perkins-Kirkpatrick, S. E., Benthuysen, J. A., Hobday, A. J., Holbrook, N. J., Moore, P. J., Thomsen, M. S., Wernberg, T. \& Smale, D. A. 2019. Projected marine heatwaves in the 21 st century and the potential for ecological impact. Frontiers in Marine Science, 6(734), 1-12.

Paalme, T., Torn, K., Martin, G., Kotta, I. \& Suursaar, Ü. 2020. Littoral benthic communities under effect of heat wave and upwelling events in NE Baltic Sea. Journal of Coastal Research, Special Issue 95, 133-137.

Perkins, S. E. \& Alexander, L. V. 2013. On the measurement of heat waves. Journal of Climatology, 26, 4500-4517.

Peterson, T. C. \& Manton, M. J. 2008. Monitoring changes in climate extremes: A tale of international collaboration. Bulletin of the American Meteorological Society, 89, 12661271.

Robine, J. M., Cheung, S. L. K., Roy, S., Oyen, H., Griffiths, C., Michel, J. P. \& Herrmann, F. R. 2008. Death toll exceeded 70,000 in Europe during the summer of 2003. Comptes Rendus Biologies, 331, 171.

Robinson, P. J. 2001. On the definition of heat wave. Journal of Applied Meteorology, 40, 762-775.

Russo, S., Sillmann, J. \& Fischer, E. M. 2015. Top ten heatwaves since 1950 and their occurrence in the coming decades. Environmental Research Letters, 10, 124003.

Rutgersson, A., Jaagus, J., Schenk, F., Stendel, M., Bärring, L., Briede, A., Claremar, B., Hanssen-Bauer, I., Holopainen, J., Moberg, A., Nordli, Ø., Rimkus, E. \& Wibig, J. 2015. Recent change - atmosphere. In The Second Assessment of Climate Change for the Baltic Sea Basin (BACC II Author Team, eds), pp. 69-97. Springer, Cham.

Ruuhela, R., Votsis, A., Kukkonen, J., Jylhä, K., Kankaanpää, S. \& Perrels, A. 2021. Temperature-related mortality in Helsinki compared to its surrounding region over two decades, with special emphasis on intensive heatwaves. Atmosphere, 12, 46.
Saava, A., Rekker, K. \& Indermitte, E. 2015. Äärmusliku kuuma ilma (sh kuumalainete) mõju rahvastiku suremusele [Impact of exceptionally hot weather (incl. heat waves) on population mortality]. Eesti Arst, 94(5), 288-293 [in Estonian, with English summary].

Schär, C., Vidale, P. L., Lüthi, D., Frei, C., Häberli, C., Liniger, M. A. \& Appenzeller, C. 2004. The role of increasing temperature variability in European summer heatwaves. Nature, 427, 332-336.

She, J., Su, J. \& Zinck, A.-S. 2020. Anomalous surface warming in the Baltic Sea in summer 2018 and mechanism analysis. Copernicus Marine Service Ocean State Report, Issue 4, Journal of Operational Oceanography, 13, sup1, s125-s132.

Siegel, H., Gerth, M. \& Tschersich, G. 2006. Sea surface temperature development of the Baltic Sea in the period 1990-2004. Oceanologia, 48(S), 119-131.

Soomere, T., Myrberg, K., Leppäranta, M. \& Nekrasov, A. 2008. The progress in knowledge of physical oceanography of the Gulf of Finland: a review for 1997-2007. Oceanologia, 50, $287-362$.

Suursaar, Ü. 2010. Waves, currents and sea level variations along the Letipea - Sillamäe coastal section of the southern Gulf of Finland. Oceanologia, 52, 391-416.

Suursaar, Ü. 2020. Combined impact of summer heat waves and coastal upwelling in the Baltic Sea. Oceanologia, 62, 511-524.

Suursaar, Ü. 2021. Winter upwelling in the Gulf of Finland, Baltic Sea. Oceanologia, 63, 356-369.

Suursaar, Ü. \& Aps, R. 2007. Spatio-temporal variations in hydro-physical and -chemical parameters during a major upwelling event off the southern coast of the Gulf of Finland in summer 2006. Oceanologia, 49, 209-228.

Suursaar, Ü., Jaagus, J. \& Tõnisson, H. 2015. How to quantify long-term changes in coastal sea storminess? Estuarine Coastal and Shelf Science, 156, 31-41.

Suursaar, Ü., Elken, J. \& Belkin, I. M. 2021. Fronts in the Baltic Sea: A review with a focus on its north-eastern part. In Chemical Oceanography of Frontal Zones (Belkin, I. M., ed). Springer Nature, https://doi.org/10.1007/698_2021_813.

SYKE. 2021. TARKKA open web service. http://syke.fi/tarkka [accessed 18 October 2021].

Takolander, A., Cabeza, M. \& Leskinen, E. 2017. Climate change can cause complex responses in Baltic macroalgae: A systematic review. Journal of Sea Research, 123, 16-29.

Uiboupin, R. \& Laanemets, J. 2009. Upwelling characteristics derived from satellite sea surface temperature data in the Gulf of Finland, Baltic Sea. Boreal Environment Research, 14, 297-304.

Zhurbas, V., Laanemets, J. \& Vahtera, E. 2008. Modeling of the mesoscale structure of coupled upwelling/downwelling events and the related input of nutrients to the upper mixed layer in the Gulf of Finland, Baltic Sea. Journal of Geophysical Research Oceans, 113, 1-8.

Zujev, M. \& Elken, J. 2018. Testing marine data assimilation in the northeastern Baltic using satellite SST products from the Copernicus Marine Environment Monitoring Service. Proceedings of the Estonian Academy of Sciences, 67, 217-230.

Zujev, M., Elken, J. \& Lagemaa, P. 2021. Data assimilation of sea surface temperature and salinity using basin-scale reconstruction from empirical orthogonal functions: a feasibility study in the northeastern Baltic Sea. Ocean Science, 17, 91-109. 


\section{1. aasta suve kuumalaine Soome lahel kliima soojenemise perspektiivis}

\section{Ülo Suursaar}

Soome lahe avaosas ja rannikualadel mõõdetud õhu- ja veetemperatuuride alusel on analüüsitud 2021. aasta suve (juuni, juuli, augusti) kuumalaineid nii atmosfääris kui mere pinnakihis. 2021. aasta suvi oli mõõtmisajaloo kuumim Eestis, mil kuumalained leidsid aset (erinevates jaamades mõõdetuna mõnevõrra erinevalt) 18.-23. juunil, 4.-10. juulil ja 13.18. juulil. Maksimaalne veetemperatuur oli 16. juulil Kundas $26,5^{\circ} \mathrm{C}$ ja 15 .-16. juulil Narva-Jõesuus $28,1^{\circ} \mathrm{C}$. Soome lahe avaosas (umbes $20 \mathrm{~km}$ rannikust) paikneval kahel lainepoil mõõdeti 14. juulil rekordiliselt kõrged veetemperatuurid: lahe keskosas paikneval lainepoil $26,6{ }^{\circ} \mathrm{C}$ (24 tunni keskmine $\left.25,5{ }^{\circ} \mathrm{C}\right)$ ning idaosas paikneval lainepoil $27,9{ }^{\circ} \mathrm{C}(24$ tunni keskmine $25,8^{\circ} \mathrm{C}$ ). Mere pinnatemperatuuri satelliidiandmete analüüsist leiti, et lahe keskmine pinnatemperatuur oli 15 . juulil $26,3^{\circ} \mathrm{C}$. Atmosfääri ja mere kuumalained ei olnud ajas päris sünkroonsed, kuna merevee pealispinna soojenemine oli mitmel korral katkestatud süvaveekergete ehk apvellingute poolt põhjustatud madalatest veetemperatuuridest, mis minimaalselt ulatusid alla 5 kraadi. Nad kahandasid merevee temperatuuri tõusu ulatust kestvate läänetuulte tingimustes Soome ranniku ääres või püsivate idatuulte korral Põhja-Eesti rannikumeres. Soome lahe piirkonna atmosfääri kuumalainete võrdluses perioodil 2010-2021olid ligikaudu võrdsetena kuumimad 2021. ja 2010. aasta suved, mille vahel olid soojemad ka 2018, 2014, 2011 ja 2019. Mere kuumalainete järjestuses oli 2021. aasta suvi kindlalt esimene. Järgnesid ligikaudu võrdsetena aastad 2014, 2010 ja 2018. Arvestades viimastel aastakümnetel toimunud Läänemere piirkonna kliima soojenemise selgeid trende, on väga ebatõenäoline, et ükski teine suvi varasematest aegadest küündiks 2021. või 2010. aasta tasemeni. 